(2) Open Access Full Text Article

\title{
Long-term safety and efficacy of romiplostim for treatment of immune thrombocytopenia
}

\author{
This article was published in the following Dove Press journal: \\ Journal of Blood Medicine \\ 25 May 2016 \\ Number of times this article has been viewed
}

\author{
Prakash Vishnu' \\ David M Aboulafia ${ }^{1,2}$ \\ 'Floyd and Delores Jones Cancer \\ Institute at Virginia Mason Medical \\ Center, ${ }^{2}$ Division of Hematology, \\ University of Washington, Seattle, WA, \\ USA
}

\begin{abstract}
Inhibition of platelet production and mediated by antiplatelet antibodies is a wellknown mechanism causing low platelet counts in immune thrombocytopenia (ITP). Use of thrombopoietin receptor agonists increases platelet counts and decreases the risk of bleeding in patients with ITP. Two such thrombopoietin receptor agonists, romiplostim and eltrombopag, are approved by the US Food and Drug Administration to treat thrombocytopenia in adults, and most recently, children with persistent or chronic ITP. This review focuses on the efficacy data and safety analysis of the pooled data from the clinical trials evaluating romiplostim for treatment of adults with ITP. The rates of hemorrhage, thrombosis, hematologic and nonhematologic cancers, and myelodysplastic syndrome were not overrepresented among the groups who received romiplostim versus placebo or other standard-of-care treatments. Yet, as after-market experience with thrombopoietin receptor agonists increases, there are emerging reports of increased incidence of thrombosis and bone marrow reticulin among patients who are treated with long-term use of these agents. Ongoing clinical research will continue to evaluate romiplostim's efficacy and safety in other primary and secondary thrombocytopenic states.
\end{abstract}

Keywords: thrombopoietin receptor agonists, romiplostim, randomized clinical trials, immune thrombocytopenia, long-term efficacy, safety

\section{Introduction}

Immune thrombocytopenia (ITP) is an immune-mediated acquired disorder characterized by transient or persistent decrease in platelet count due to decreased production and increased peripheral destruction of platelets secondary to antiplatelet antibodies. Based on the International Working Group's standardization of terminology, ITP is categorized as "newly diagnosed" from diagnosis until 3 months, "persistent" if thrombocytopenia lasts 3-12 months, and "chronic" if it lasts for longer than 12 months. ${ }^{1}$

ITP often occurs in the absence of a discernible cause, making it a diagnosis of exclusion. It is most often diagnosed incidentally on a routine complete blood count, but may also manifest clinically with mucocutaneous bleeding or dependent purpura involving the lower extremities. ITP in adults is heterogeneous - some patients may have no stigmata of low platelet counts and remain clinically asymptomatic while others will have bleeding manifestations from the outset. ${ }^{2}$ Recently, Li et al reported that among 3,000 ITP patients, 73\% had at least one episode of bleeding with the rate being the highest during the first 3 months of diagnosis. The types of bleeds noticed most frequently in this patient cohort were gastrointestinal bleeding, hematuria, epistaxis, and ecchymosis, with intracranial hemorrhage occurring in $5 \%$ of patients with bleeds. ${ }^{3}$
Floyd and Delores Jones Cancer Institute at Virginia Mason Medical Center, I 100 Ninth Avenue (C2-HEM), Seattle, WA 98101 , USA

Tel +I 20634 I I284

Fax + I 206223 69I4

Email hemdma@virginiamason.org
Journal of Blood Medicine 2016:7 99-106

(c) (7) (ㅇ) 2016 Vishnu and Aboulafia. This work is published and licensed by Dove Medical Press Limited. The full terms of this license are available at https://www.dovepress.com/ (c) work you hereby accept the Terms. Non-commercial uses of the work are permitted without any further permission from Dove Medical Press Limited, provided the work is properly attributed. For permission for commercial use of this work, please see paragraphs 4.2 and 5 of our Terms (https://www.dovepress.com/terms.php).
Dovepress

http://dx.doi.org/10.2147/JBM.S80646 
Our understanding of the pathophysiology of ITP and the approach to its treatment have evolved significantly over the past few decades: from identification of the disease as a platelet-destruction process in the peripheral blood to an immune-mediated process as the cause of the destruction; and, further, as a suboptimal production of platelets due to inhibition of megakaryocytes., ${ }^{4,5}$

The discovery of the platelet-production stimulator thrombopoietin (TPO; or c-MPL ligand) was the proofof-principle to the hypothesis that inhibition of platelet production at the level of the megakaryocyte contributes to thrombocytopenia in adults with ITP. ${ }^{6,7}$ Activation of the TPO receptor (MPL), which is present on megakaryocyte precursors, megakaryocytes, and platelets, leads to increased thrombopoiesis. ${ }^{8}$ This seminal finding facilitated TPO-based therapies as treatment for ITP. However, further production of a recombinant human TPO (rh-TPO) was halted after initial clinical trials showed that when healthy study volunteers received rh-TPO, they became severely thrombocytopenic owing to cross-reactivity between autoantibodies to rh-TPO and endogenous TPO. This led to the formulation of a new category of agents that stimulate the TPO receptor but with minimal or no immunogenic effects. These new agents belong to one of the three categories: TPO peptide mimetics (eg, romiplostim), TPO nonpeptide mimetics (eg, eltrombopag), and TPO antibody mimetics.

On August 22, 2008, the US Food and Drug Administration (FDA) approved romiplostim as a long-term treatment for persistent or chronic ITP in adults who had not responded to other conventional treatments. ${ }^{9}$ It had been named AMG531 during development and clinical trials, and is now marketed under the trade name Nplate ${ }^{\circledR}$ (Amgen Inc., Thousand Oaks, CA, USA). After the FDA approval for clinical use, it was accessible through a restricted usage program called NEXUS, but in December 2011, the US FDA removed certain elements of the risk evaluation and mitigation strategies, including the requirements for restricted distribution and additional safety data collection. ${ }^{9,10}$ We will review salient information regarding the efficacy and safety of romiplostim in adult patients with ITP.

\section{Treatment of ITP}

In patients with ITP, the goal of treatment is to raise platelet counts to a level that will minimize or stop bleeding. The platelet count that has traditionally been considered safe has been variable and depends on a multitude of clinical factors, but the value that is most widely accepted as satisfactory to maintain adequate hemostasis is around $10-20 \times 10^{9} / \mathrm{L}$ in patients with stable chronic disease and without any additional bleeding diathesis. In those patients poised to undergo surgical procedures, the preferred levels are above $30 \times 10^{9} / \mathrm{L}$ for dental procedures, $50 \times 10^{9} / \mathrm{L}$ for minor surgical procedures, and greater than $80 \times 10^{9} / \mathrm{L}$ for major surgical procedures. Bleeding usually occurs in patients with rapidly falling platelet counts and, in such situations, treatment to increase platelet counts may need to be initiated earlier. In the absence of planned procedures, the American Society of Hematology 2014 Choosing Wisely ${ }^{\circledR}$ campaign emphasizes that patients with ITP should not be treated unless they are bleeding or have very low platelet counts. ${ }^{11}$

Conventional treatments for ITP include immunosuppressive therapies that primarily aim to reduce platelet destruction (eg, corticosteroids, azathioprine, cyclosporine A, cyclophosphamide, mycophenolate mofetil, rituximab, and vinca alkaloids), Fc receptor blockade which prevents macrophage destruction of antibody-coated platelets (eg, intravenous immunoglobulin and intravenous anti-D), and surgical therapy which prevents platelet sequestration (ie, splenectomy). However, patients with ITP do not always respond to conventional "immunosuppressive" treatments, each of which carries its own risk of adverse side effects. For those patients whose platelet counts do not respond to steroids, there is little consensus as to how to layer additional therapies and only a handful of options are associated with strong evidence regarding their utility. ${ }^{12}$ More importantly, these treatments have shown a wide range of risks, the most severe of which are related to immunosuppression. In this context, based on the concept of impaired thrombopoiesis in ITP, recent developments have focused on newer, less immunogenic TPO receptor agonists that increase the production of megakaryocytes and by extension platelets. ${ }^{13}$

\section{Romiplostim: development and evaluation}

Romiplostim, identified as AMG531 during development and clinical trials, is now marketed under the trade name Nplate $^{\circledR}$. It is a recombinant Fc-peptide fusion protein with two domains: a peptide domain that binds to the TPO receptor and activates intracellular pathways stimulating thrombopoiesis, and a carrier antibody with a crystallized fragment domain. The crystallized fragment domain undergoes endothelial recirculation, thereby prolonging its circulating half-life. Romiplostim has no sequence homology with endogenous human TPO, and as such does not lower platelet counts as was seen with the seminal studies involving rh-TPO. ${ }^{14-16}$ 


\section{Preclinical studies with romiplostim}

In vitro experiments with murine and human megakaryocytes showed that romiplostim binds to the TPO receptor in a similar fashion as endogenous TPO. ${ }^{17,18}$ In a dose-dependent fashion, romiplostim stimulates the growth and maturation of murine colony-forming units-megakaryocytes. As with endogenous TPO, exposure of cells that express human TPO receptor to romiplostim leads to rapid tyrosine phosphorylation of Janus 2 kinase and STAT5 transcription factor, and stimulation of megakaryopoiesis. ${ }^{16}$ Romiplostim displaces recombinant radiolabeled TPO from the TPO receptor in these cells, and augments the effects of TPO on murine megakaryopoiesis. In a murine marrow culture model, romiplostim also stimulated megakaryocyte colony-forming units and megakaryopoiesis in a dose-dependent fashion. ${ }^{17}$

In vivo studies using rhesus monkeys showed that a single dose of romiplostim led to a dose-dependent increase in platelet count at day 5 with a peak increase between days 7 and 9. Stimulation of megakaryopoiesis was seen at romiplostim concentrations as low as $30 \mathrm{ng} / \mathrm{mL}$ and was maximal at concentrations between 1,000 and $2,000 \mathrm{ng} / \mathrm{mL}$. These effects were enhanced in the presence of erythropoietin, stem cell factor, and interleukin-3 and -6. No subsequent thrombocytopenia was observed and neutralizing anti-TPO antibodies were not detected. These promising preclinical data led to initial human clinical trials beginning in $2004 .{ }^{19}$

\section{Phase I-II clinical trials}

Wang et $\mathrm{al}^{20}$ reported the first randomized, double-blind, placebo-controlled study in humans, which included 48 healthy volunteers. They were treated with a single intravenous $(0.3-10.0 \mu \mathrm{g} / \mathrm{kg})$ or subcutaneous dose $(0.1-2.0 \mu \mathrm{g} / \mathrm{kg})$ of romiplostim. Peak platelet counts were achieved on days 12-16. The drug showed good tolerability with either delivery - patients most frequently reported mild to moderate headache and sore throat, and there were no serious or lifethreatening adverse events identified in this study.

Two Phase I-II trials, one in the US and one in Europe, were conducted in patients with ITP who remained thrombocytopenic despite undergoing splenectomy. ${ }^{21,22}$ Both clinical trials showed that romiplostim boosted platelet counts in a dose-dependent fashion. In the US study, which included a total of 24 patients, a platelet count of at least $50 \times 10^{9} / \mathrm{L}$ was achieved in seven of 12 patients treated with 3,6 , or $10 \mu \mathrm{g} / \mathrm{kg}$ romiplostim. ${ }^{21}$ The platelet count was within the target range $\left(50,000-450,000 \times 10^{9} / \mathrm{L}\right)$ in four patients and above the target range (ie, $>450 \times 10^{9} / \mathrm{L}$ ) in three patients.
In the European study, which had a total of 16 patients, four patients were assigned to each of the four unit-dose cohorts: $30,100,300$, or $500 \mu \mathrm{g}$ of romiplostim, administered subcutaneously on days 1 and 15 (or day 22 if day 15 platelet count was $\left.>50 \times 10^{9} / \mathrm{L}\right){ }^{23}$ Treatment with the $500 \mu \mathrm{g}$ romiplostim dose was discontinued because of an excessively high platelet count measured in the first patient so treated. Platelet responses occurred with all doses and with a dose equivalent of greater than or equal to $1 \mu \mathrm{g} / \mathrm{kg}$ in eight of eleven patients. Adverse events were generally mild or moderate; the most frequent was headache reported in eight of 16 patients. Transient rebound thrombocytopenia after discontinuation of romiplostim, likely resulting from enhanced clearance of endogenous TPO by the increased number of megakaryocytes, was reported in $10 \%(4 / 40)$ of patients in these two study cohorts..$^{21}$ It is for this reason that a gradual de-escalation of the dose of romiplostim is suggested in the package insert instead of abruptly stopping treatment. ${ }^{10}$

\section{Phase III clinical trials}

The two pivotal placebo-controlled Phase III trials, which were conducted in parallel at centers in the US and Europe, led to the approval of romiplostim by the US FDA for treatment of chronic ITP in 2008.22 Both the trials had identical study designs except that one enrolled chronic ITP patients who had undergone splenectomy $(n=63)$ and the other trial enrolled patients with intact spleens $(n=62)$. Patients with ITP and a mean of three platelet counts $\leq 30 \times 10^{9} / \mathrm{L}$ were randomly assigned 2:1 to subcutaneous injections of romiplostim ( $\mathrm{n}=42$ in patients treated with splenectomy and $n=41$ in nonsplenectomy patients) or placebo ( $\mathrm{n}=21$ in both studies) every week for 24 weeks. The primary objective was to assess the efficacy of romiplostim as measured by a durable platelet response (platelet count $\geq 50 \times 10^{9} / \mathrm{L}$ during six or more of the last 8 weeks of treatment).

Platelet response-adapted dosing of romiplostim as was followed in these studies is outlined in Table 1. The maximum permitted dose was $15 \mu \mathrm{g} / \mathrm{kg}$. The primary endpoint in both studies was durable platelet response defined by a platelet count $\geq 50 \times 10^{9} / \mathrm{L}$ during at least six of the last 8 weeks of treatment, without receiving rescue medication at any point in the trial. A transient response was defined as four or more weekly platelet responses without a durable response during weeks 2 through 25. Patients assessed as having had a transient response were not allowed to have received any rescue medications within 8 weeks of the response. In both studies, the median baseline platelet count was $16 \times 10^{9} / \mathrm{L}$ (range $2-31 \times 10^{9} / \mathrm{L}$ ). The median duration of ITP was $\sim 8$ years in 
Table I Platelet response-adapted dosing of romiplostim

Starting dose:

- I $\mu \mathrm{g} / \mathrm{kg}$

Subsequent dosing:

- $2 \mu \mathrm{g} / \mathrm{kg}$ every week if $10 \times 10^{9} / \mathrm{L}$ or less

- $2 \mu \mathrm{g} / \mathrm{kg}$ every 2 weeks if $11 \times 10^{9} / \mathrm{L}$ to $50 \times 10^{9} / \mathrm{L}$

Maintenance dosing:

- Increase dose by I $\mu \mathrm{g} / \mathrm{kg}$ every week if $<10 \times 10^{9} / \mathrm{L}$

- Increase dose by I $\mu \mathrm{g} / \mathrm{kg}$ after 2 weeks if $11 \times 10^{9} / \mathrm{L}$ to $50 \times 10^{9} / \mathrm{L}$

- No dose adjustment if 50-200 $\times 10^{9} / \mathrm{L}$

- Reduce dose by I $\mu \mathrm{g} / \mathrm{kg}$ after 2 consecutive weeks if $201 \times 10^{9} / \mathrm{L}-400 \times 10^{9} / \mathrm{L}$

- Hold dose if $>400 \times 10^{9} / \mathrm{L}$. Check platelet count weekly; resume at dose reduced by I $\mu \mathrm{g} / \mathrm{kg}$ after platelet count $<200 \times 10^{9} / \mathrm{L}$

Maximum allowed dose: $15 \mu \mathrm{g} / \mathrm{kg}$

Note: Data from Kuter et al. ${ }^{22}$

those with prior splenectomy, and $\sim 2$ years in those with intact spleens. The majority of patients had received $\geq 3$ previous lines of treatments for ITP.

Administration of romiplostim led to a durable platelet response in 16 of the 42 patients (38\%) who had undergone a splenectomy and 25 of the 41 patients (61\%) with spleens. Corresponding figures for the placebo group were $0 / 21(0 \%)$ and $1 / 21(5 \%)$, respectively. The results demonstrated a treatment difference of $38 \%$ ( $95 \%$ CI, $23 \%$ to $53 \%$; $P=0.0013$ ) in splenectomy patients, and $56 \%(95 \% \mathrm{CI}, 39 \%$ to $74 \%$; $P<0.0001$ ) in patients with spleens (Table 2). Overall, durable or transient platelet responses were achieved in 33 of 42 (79\%) of splenectomy patients treated with romiplostim and 36 of $41(88 \%)$ of patients with spleens treated with romiplostim. In contrast, $0 \%(0)$ and $14 \%$ (3 of 21) of patients, respectively, in the placebo groups had platelet responses. Patients treated with romiplostim were able to maintain a platelet count of $\geq 50 \times 10^{9} / \mathrm{L}$ for a mean of 15.2 weeks in the nonsplenectomy group, and 12.3 weeks in the splenectomy group. Almost a third of patients were taking concomitant ITP medications (eg, corticosteroids, azathioprine, and danazol) at baseline. Among romiplostim treated patients, $87 \%$ were able to discontinue their various ITP treatments or substantially reduce dosage (by $\geq 25 \%$ ) compared with only $38 \%$ of those who received placebo.

Similar efficacy results were reported in another randomized study from Japan. ${ }^{24}$ Thirty-four patients with chronic ITP were treated with romiplostim $(n=22)$ or placebo $(n=12)$ for a total of 12 weeks, with a starting romiplostim dose of $3 \mu \mathrm{g} / \mathrm{kg}$ weekly. The primary endpoint was the number of weeks with platelet response, defined as a platelet count $\geq 50 \times 10^{9} / \mathrm{L}$. Weekly responses occurred for a median of 11 weeks with romiplostim as compared to 0 weeks with placebo $(P<0.0001)$ and $95 \%$ of patients treated with romiplostim achieved target platelet responses.

\section{Adverse events}

While adverse events were reported in all patients treated with romiplostim $(83 / 83 ; 100 \%)$ in the pivotal Phase III trials, most events were mild to moderate with only three patients $(4 \%)$ in the cohort discontinuing romiplostim. ${ }^{22}$ Headache was the most common adverse event reported by patients receiving romiplostim $(29 / 83 ; 35 \%)$, followed by fatigue $(28 / 83 ; 33 \%)$, epistaxis $(27 / 83 ; 32 \%)$, and arthralgia $(22 / 83 ; 26 \%)$.

Ironically, thromboembolic events are a well-known concern in patients with ITP. ${ }^{25}$ There was no evidence from these two studies that romiplostim increased the risk for such events; the overall incidence of thromboembolic events was $2.4 \%$ in both the romiplostim and placebo groups. Clinically significant bleeding events ( $\geq$ grade 2 ) were noted in $16 \%$ of romiplostim and $34 \%$ of placebo-treated patients $(P=0.018)$. Bleeding events $\geq$ grade 3 were seen in $7 \%$ and $12 \%$ of the patients in the romiplostim and placebo groups, respectively $(P=0.36)$.

Serious treatment-related adverse events were reported in two romiplostim-treated patients. After 7 weeks of treatment, one patient had increased bone marrow reticulin, and discontinuation of romiplostim led to return of reticulin to baseline levels 14 weeks later. A second patient, an 82-year-old man

Table 2 Platelet response in placebo-controlled studies ${ }^{22}$

\begin{tabular}{|c|c|c|c|c|}
\hline \multirow[t]{2}{*}{ Outcomes } & \multicolumn{2}{|c|}{$\begin{array}{l}\text { Study I } \\
\text { (nonsplenectomized patients) }\end{array}$} & \multicolumn{2}{|c|}{$\begin{array}{l}\text { Study } 2 \\
\text { (splenectomized patients) }\end{array}$} \\
\hline & $\begin{array}{l}\text { Romiplostim } \\
(n=4 I)\end{array}$ & $\begin{array}{l}\text { Placebo } \\
(n=21)\end{array}$ & $\begin{array}{l}\text { Romiplostim } \\
(n=42)\end{array}$ & $\begin{array}{l}\text { Placebo } \\
(n=2 I)\end{array}$ \\
\hline Overall platelet response, n (\%) & $36(88)$ & $3(14)$ & $33(79)$ & $0(0)$ \\
\hline Durable platelet response, $\mathrm{n}(\%)$ & $26(6 I)$ & $\mathrm{I}(5)$ & $16(38)$ & $0(0)$ \\
\hline Requiring rescue therapy, n (\%) & $8(20)$ & $13(62)$ & II (26) & $12(57)$ \\
\hline $\begin{array}{l}\text { Average number of weeks with platelet counts } \\
\geq 50 \times 10^{9} / \mathrm{L}\end{array}$ & 15 & 1 & 12 & 0 \\
\hline
\end{tabular}

Notes: Reprinted from The Lancet. Lancet 2008;37I (96/0), Kuter DJ, Bussel JB, Lyons RM, et al. Efficacy of romiplostim in patients with chronic immune thrombocytopenic purpura: a double-blind randomised controlled trial.395-403. Copyright 2008, with permission from Elsevier. ${ }^{22}$ All $P$-values $<0.05$ for platelet response and rescue therapy. 
with peripheral vascular disease and atrial fibrillation, was diagnosed with a right popliteal artery embolism and underwent a successful embolectomy. Other than abnormal platelet counts, no clinically significant treatment-related changes in vital signs or in hematological or serum chemistry values occurred in any of the patients participating in these pivotal Phase III studies. Furthermore, there were no antibodies against romiplostim or TPO among study participants.

\section{Long-term safety and efficacy}

Kuter et $\mathrm{al}^{26}$ reported the safety and efficacy of romiplostim in 291 adult patients with chronic ITP in a long-term, single arm, multicenter open-label extension study. Four treatment cohorts received weekly romiplostim for as long as 5 years between April 2004 and May 2009. All patients had previously been entered into romiplostim studies.

There were several marked differences between the first three cohorts $(n=152)$ and the last (fourth) cohort $(n=139)$. The first three cohorts consisted of patients with more refractory ITP. The majority of the patients who had undergone splenectomy were from cohorts $1(79 \%), 2$, or 3 ; only $1 \%$ of patients in cohort 4 had undergone splenectomy. The median baseline platelet count for the first three cohorts was $\leq 19 \times 10^{9} / \mathrm{L}$, and the median time since ITP diagnosis ranged from 5.6 to 10.9 years. For cohort 4 , the median platelet count was $111 \times 10^{9} / \mathrm{L}$, and the median time since ITP diagnosis was 3.1 years.

The maximum dose of romiplostim allowed for cohorts 1 through 3 was $30 \mu \mathrm{g} / \mathrm{kg}$, whereas in the final cohort, the dose was restricted to $10 \mu \mathrm{g} / \mathrm{kg}$. The duration of treatment with romiplostim varied from 1 to 277 weeks, with a mean of 110 weeks with a total of 614 patient-years of romiplostim exposure. The mean romiplostim dose was $5-8 \mu \mathrm{g} / \mathrm{kg}$. The median platelet count increased during the first month and then remained steady at a value between $120 \times 10^{9} / \mathrm{L}$ and $140 \times 10^{9} / \mathrm{L}$ for most of the study duration with more than $95 \%$ of all patients (97\% in patients with spleens; $90 \%$ in splenectomy patients) achieving a platelet response $\geq 50 \times 10^{9} / \mathrm{L}$ at any time during the study.

The incidence of adverse events in each cohort of patients receiving long-term romiplostim treatment for chronic ITP is summarized in Table 3. Treatment-related adverse events were highest in cohort 1: the cohort with the highest splenectomy rate, most refractory disease, highest average dose of romiplostim, and longest duration of romiplostim treatment. Treatment-related adverse events were less in each of the subsequent cohorts. Overall, 284 of the 291 patients (98\%) had experienced side effects. The most common adverse events were headache (38\%), nasopharyngitis (34\%), fatigue $(32 \%)$, contusion $(31 \%)$, upper respiratory tract infection (26\%), diarrhea (25\%), and epistaxis (25\%).

While nearly all patients (98\%) experienced adverse events, only $8 \%(24 / 291)$ experienced treatment-related serious adverse events; the most common treatment-related serious adverse events were thrombocytopenia (4/291; $1.4 \%)$ and increased bone marrow reticulin (4/291; 1.4\%). However, the incidence of increased bone marrow reticulin was most assuredly underestimated as a bone marrow biopsy was performed in only 38 patients and this procedure was largely restricted to those patients who had failed to show an adequate response to romiplostim. Bone marrow reticulin was increased in eleven of the 38 patients, only four of which were reported as adverse events by the study investigators. Modest but benign increases in reticulin have also been seen with eltrombopag suggesting that reticulin deposition may be a characteristic of this drug class. ${ }^{27}$

Twenty-five thrombotic events were seen in 19 patients $(6.5 \%)$ : ten myocardial infarctions, six neurological events, and nine venous thrombotic events. No correlation was seen between thrombotic events and posttreatment platelet counts. Two patients had transient neutralizing antibodies to romiplostim, but these did not cross-react to endogenous TPO or affect the platelet response and disappeared when retested after withdrawal of romiplostim. Of the 16 deaths

Table 3 Incidence of adverse events in patients receiving long-term romiplostim treatment for chronic ITP 26

\begin{tabular}{|c|c|c|c|c|c|}
\hline & $\begin{array}{l}\text { Cohort I } \\
(n=33)\end{array}$ & $\begin{array}{l}\text { Cohort } 2 \\
(n=88)\end{array}$ & $\begin{array}{l}\text { Cohort } 3 \\
(n=3 I)\end{array}$ & $\begin{array}{l}\text { Cohort } 4 \\
(n=139)\end{array}$ & $\begin{array}{l}\text { Total } \\
(n=291)\end{array}$ \\
\hline Any AE, n (\%) & $32(97)$ & $88(100)$ & $30(97)$ & $134(96)$ & $284(98)$ \\
\hline Serious AE, n (\%) & $18(55)$ & $40(46)$ & $14(45)$ & $45(32)$ & $117(40)$ \\
\hline Treatment-related AE, n (\%) & $18(55)$ & $37(42)$ & $10(32)$ & $38(27)$ & $103(35)$ \\
\hline Treatment-related serious AE, n (\%) & $8(24)$ & $3(3)$ & $5(16)$ & $8(6)$ & $24(8)$ \\
\hline Deaths, n (\%) & $0(0)$ & $6(7)$ & $3(10)$ & $7(5)$ & $16(5)$ \\
\hline Thrombotic events, n (\%) & $5(15)$ & $5(6)$ & $8(26)$ & $7(5)$ & $19(7)$ \\
\hline Bleeding events, n (\%) & $30(91)$ & $63(72)$ & $23(74)$ & $50(36)$ & $166(57)$ \\
\hline
\end{tabular}

Note: Reprinted from Br J Haematol. Kuter DJ, Bussel JB, Newland A, et al. Long-term treatment with romiplostim in patients with chronic immune thrombocytopenia: safety and efficacy. 20I3;16I(3):4II-423. Copyright 20I3, with permission from John Wiley and Sons. ${ }^{26}$

Abbreviations: $A E$, adverse event; ITP, immune thrombocytopenia. 
that occurred during the study, two were considered by the investigators to be possibly related to romiplostim. One patient succumbed from a myocardial infarction, and the other died from complications of unstable angina. Both patients had pre-existing cardiovascular risk factors, and there was no evident relationship between patient death and romiplostim treatment duration or platelet count.

More recently, Cines et $\mathrm{al}^{28}$ provided an integrated analysis of long-term safety of romiplostim. Data from 14 studies conducted between July 2002 and June 2011 were included. A total of 921 patients had received romiplostim for up to 5.4 years for a total exposure of 1,520 patient-years with a mean treatment duration of 76 weeks. The mean weekly dose of romiplostim was $4.2 \mu \mathrm{g} / \mathrm{kg}$. Similar to the findings of Kuter et al, ${ }^{26}$ the most frequent duration-adjusted adverse events with romiplostim in this composite analyses included headache, contusion, epistaxis, and nasopharyngitis; no new safety concerns were identified. The rate of thrombotic events was 5.5/100 patient-years. The most common types of thrombotic events were deep venous thrombosis $(1.1 / 100$ patientyears), pulmonary embolism (0.9/100 patient-years), and myocardial infarction $(0.6 / 100$ patient-years $)$. Thrombotic events occurred across a wide range of platelet counts and did not appear to correlate with time above platelet thresholds. Increased bone marrow reticulin was reported in 17 patients and increased bone marrow collagen in one patient receiving romiplostim. Three patients had neutralizing antibodies to romiplostim, but not to endogenous TPO.

Similar efficacy and safety data have been demonstrated in pediatric patients with ITP treated with romiplostim. ${ }^{29-32}$ Bussel et $\mathrm{al}^{29}$ described their experience in treating a cohort of 17 pediatric patients whose median age was 10 years and who received weekly subcutaneous romiplostim, adjusted by $1 \mathrm{mg} / \mathrm{kg} /$ week to maintain platelet counts $\left(50-200 \times 10^{9} / \mathrm{L}\right.$, maximum dose $10 \mathrm{mg} / \mathrm{kg}$ ). Romiplostim increased and maintained platelet counts for over 4 years in children with ITP with good tolerability and without significant toxicity; there were no fatalities or other serious adverse events attributed to romiplostim.

In an antecedent Phase I/II study, Bussel et $\mathrm{al}^{30}$ treated children with ITP of $\geq 6$ months' duration with subcutaneous injections of romiplostim $(n=17)$ or placebo $(n=5)$ weekly for 12 weeks, with dose adjustments to maintain platelet counts between $50 \times 10^{9} / \mathrm{L}$ and $250 \times 10^{9} / \mathrm{L}$. A platelet count $\geq 50 \times 10^{9} / \mathrm{L}$ for two consecutive weeks was achieved by $15 / 17$ $(88 \%)$ patients in the romiplostim group and no patients in the placebo group; this response was maintained for a median of 7 weeks in romiplostim group and 0 weeks in placebo group.
The median weekly dose of romiplostim at 12 weeks was $5 \mu \mathrm{g} / \mathrm{kg}$. There were no treatment-related, serious adverse events. The most commonly reported adverse events in children, as in adults, were headache and epistaxis.

In a placebo-controlled study from Egypt, ten of the 12 pediatric patients randomized to receive romiplostim for 12 weeks (initiated at $1 \mu \mathrm{g} / \mathrm{kg} /$ week and escalated as needed up to $5 \mu \mathrm{g} / \mathrm{kg} /$ week) maintained the efficacy endpoint of platelet count $\geq 50 \times 10^{9} / \mathrm{L} .{ }^{31}$ Median dose was $2 \mu \mathrm{g} / \mathrm{kg} /$ week, and none of the patients had any serious adverse events.

Pasquet et $\mathrm{al}^{32}$ also studied the use of romiplostim in pediatric patients with ITP. In a retrospective national analysis for the CEREVANCE (Centre de Rèfèrence National des Cytopènies Auto-immunes de l'Enfant), they reported that five out of ten patients with childhood nonresponsive or refractory chronic ITP achieved response (one patient with complete response defined by a platelet count of $>100 \times 10^{9} / \mathrm{L}$ and absence of bleeding; four patients with response defined as a platelet count between 30 and $100 \times 10^{9} / \mathrm{L}$, at least doubling of the baseline count, and absence of bleeding) with romiplostim. The median duration of treatment was 9 months. At the end of the study, with a median follow-up of 25 months (range 20-42 months) since initiation of romiplostim treatment, one patient was still receiving romiplostim, while three patients had discontinued therapy after 12,11 , and 7 months, respectively, because of response and owing to the absence of long-term safety data in children. None of the ten patients experienced treatment-related serious adverse events.

\section{Conclusion}

Romiplostim is one of two novel targeted agents that are available for clinical use for treatment of chronic ITP. It works by activating the TPO receptor leading to increased production of megakaryocytes. Unlike the previous generation of TPO receptor agonists, it does not induce immunogenicity with resultant thrombocytopenia. Early Phase I/II clinical trials of romiplostim showed promise across a broad range of doses in patients with chronic ITP. Standard dosing schemas were further refined in several additional Phase III randomized clinical trials. Also, these trials showed that romiplostim was well tolerated with patients experiencing very few significant side effects. Platelet responses were durable while undergoing treatment with romiplostim, with the majority of patients maintained on romiplostim on a once a week schedule, and with some patients being able to reduce the dose over time. Bleeding episodes, which is a more clinically meaningful endpoint for patients with chronic ITP, were also reduced. The benefits of romiplostim in other disease states associated with 
low platelet counts, including hepatitis $\mathrm{C}$, human immunodeficiency virus infection, and antiphospholipid antibody syndrome, to name but a few, require further investigation.

A global pharmacovigilance program is underway to fully understand the real and potential adverse events with long-term use of romiplostim. Fortunately, the long-term safety of romiplostim compiled from several prospective clinical trials suggests that there is no significant increase in the rates of adverse events, including bone marrow reticulin and thrombosis, among adults with chronic ITP. ${ }^{26-28}$

While TPO receptor agonists have been licensed for use in adult and pediatric patients with chronic and refractory ITP, further safety and efficacy data and analysis of their use in newly diagnosed ITP may allow us to use these agents earlier on in the disease course.

TPO receptor agonists are typically used for treatment of ITP after failing front line therapies such as steroids or rituximab, but the with the data from ongoing trials, we may be able to use these agents early on as first or second line agents in ITP.

However, it remains unclear how long patients with ITP will have to continue romiplostim. Some studies suggest that romiplostim may be discontinued in select patients, even though there are concerns of a profound rebound thrombocytopenia following its discontinuation. ${ }^{33-35}$ This is not a trivial question. Current wholesale price of romiplostim is $\$ 1,062.50$ for a single-use vial of $250 \mu \mathrm{g}$ or $\$ 2,125.00$ for a single-use vial of $500 \mu \mathrm{g} .{ }^{36}$ Most patients who respond to romiplostim will require a dose of $<250 \mu \mathrm{g}$. The extrapolated drug cost for weekly dosing of romiplostim for 1 year is $\sim \$ 55,250$. Given that this drug is expensive, it behooves clinicians to better understand when and how to taper this drug for patients with chronic ITP.

\section{Disclosure}

The authors report no conflicts of interest in this work.

\section{References}

1. Rodeghiero F, Stasi R, Gernsheimer T, et al. Standardization of terminology, definitions and outcome criteria in immune thrombocytopenic purpura of adults and children: report from an international working group. Blood. 2009;113(11):2386-2393.

2. Cines DB, Bussel JB. How I treat idiopathic thrombocytopenic purpura (ITP). Blood. 2005;106(7):2244-2251.

3. Li S, Molony JT, Cetin K, Wasser JS, Altomare I. Rate of bleeding-rated episodes (BREs) in elderly patients with primary immune thrombocytopenia (ITP): A population-based retrospective cohort study using medicare $20 \%$ sample data. Clinically Relevant Abstract. In: ASH Annual Meeting and Exposition; 2015; Orlando, FL.

4. Branehog I, Kutti J, Weinfeld A. Platelet survival and platelet production in idiopathic thrombocytopenic purpura (ITP). Br J Haematol. 1974;27(1):127-143.
5. Ballem PJ, Segal GM, Stratton JR, Gernsheimer T, Adamson JW, Slichter SJ. Mechanisms of thrombocytopenia in chronic autoimmune thrombocytopenic purpura. Evidence of both impaired platelet production and increased platelet clearance. J Clin Invest. 1987;80(1):33-40.

6. Fox JE. Platelet activation: new aspects. Haemostasis. 1996;26(Suppl 4): $102-131$.

7. Machlus KR, Italiano JE Jr. The incredible journey: From megakaryocyte development to platelet formation. J Cell Biol. 2013;201(6):785-796.

8. Kaushansky K. Thrombopoietin: the primary regulator of platelet production. Blood. 1995;86(2):419-431.

9. FDA Drug Safety Communication: Modified Risk Evaluation and Mitigation Strategies (REMS) for Nplate (romiplostim) and Promacta (eltrombopag); 2011. Available from: http://www.fda.gov/Drugs/DrugSafety/ucm280165.htm\#. Accessed December 28, 2015.

10. Nplate Prescribing Information and Medication Guide; 2011. Available from: http://www.nplatehcp.com/nplate/nplate-nexus. Accessed December 28, 2015.

11. Hicks LK, Bering H, Carson KR, et al. The ASH Choosing Wisely(R) campaign: five hematologic tests and treatments to question. Blood. 2013;122(24):3879-3883.

12. Ghanima W, Godeau B, Cines DB, Bussel JB. How I treat immune thrombocytopenia: the choice between splenectomy or a medical therapy as a second-line treatment. Blood. 2012;120(5):960-969.

13. Mitchell WB, Bussel JB. Thrombopoietin receptor agonists: a critical review. Semin Hematol. 2015;52(1):46-52.

14. Cwirla SE, Balasubramanian P, Duffin DJ, et al. Peptide agonist of the thrombopoietin receptor as potent as the natural cytokine. Science. 1997;276(5319):1696-1699.

15. Kuter DJ, Begley CG. Recombinant human thrombopoietin: basic biology and evaluation of clinical studies. Blood. 2002;100(10):3457-3469.

16. Broudy VC, Lin NL. AMG531 stimulates megakaryopoiesis in vitro by binding to Mpl. Cytokine. 2004;25(2):52-60.

17. Broudy VC, Lin NL, Kaushansky K. Thrombopoietin (c-mpl ligand) acts synergistically with erythropoietin, stem cell factor, and interleukin-11 to enhance murine megakaryocyte colony growth and increases megakaryocyte ploidy in vitro. Blood. 1995;85(7):1719-1726.

18. Currao M, Balduini CL, Balduini A. High doses of romiplostim induce proliferation and reduce proplatelet formation by human megakaryocytes. PloS One. 2013;8(1):e54723.

19. Sun YN, Arends R, Smithson A, Watson A, Nichol JL. A novel thrombopoiesis-stimulating agent, AMG 531: Pharmacokinetics and pharmacodynamics in FcRn knock-out and wild type mice. Blood. 2005;106:3575.

20. Wang B, Nichol JL, Sullivan JT. Pharmacodynamics and pharmacokinetics of AMG 531, a novel thrombopoietin receptor ligand. Clin Pharmacol Ther. 2004;76(6):628-638.

21. Bussel JB, Kuter DJ, George JN, et al. AMG 531, a thrombopoiesisstimulating protein, for chronic ITP. $N$ Engl $J$ Med. 2006;355(16): $1672-1681$.

22. Kuter DJ, Bussel JB, Lyons RM, et al. Efficacy of romiplostim in patients with chronic immune thrombocytopenic purpura: a doubleblind randomised controlled trial. Lancet. 2008;371(9610):395-403.

23. Newland A, Caulier MT, Kappers-Klunne M, et al. An open-label, unit dose-finding study of AMG 531, a novel thrombopoiesis-stimulating peptibody, in patients with immune thrombocytopenic purpura. $\mathrm{Br} J$ Haematol. 2006;135(4):547-553.

24. Shirasugi Y, Ando K, Miyazaki K, et al. Romiplostim for the treatment of chronic immune thrombocytopenia in adult Japanese patients: a double-blind, randomized Phase III clinical trial. Int $J$ Hematol. 2011;94(1):71-80.

25. Ruggeri M, Tosetto A, Palandri F, et al. Thrombotic risk in patients with primary immune thrombocytopenia is only mildly increased and explained by personal and treatment-related risk factors. J Thromb Haemost. 2014;12(8):1266-1273.

26. Kuter DJ, Bussel JB, Newland A, et al. Long-term treatment with romiplostim in patients with chronic immune thrombocytopenia: safety and efficacy. Br J Haematol. 2013;161(3):411-423. 
27. Brynes RK, Orazi A, Theodore D, et al. Evaluation of bone marrow reticulin in patients with chronic immune thrombocytopenia treated with eltrombopag: Data from the EXTEND study. Am J Hematol. 2015;90(7):598-601.

28. Cines DB, Gernsheimer T, Wasser J, et al. Integrated analysis of longterm safety in patients with chronic immune thrombocytopaenia (ITP) treated with the thrombopoietin (TPO) receptor agonist romiplostim. Int J Hematol. 2015;102(3):259-270.

29. Bussel JB, Hsieh L, Buchanan GR, et al. Long-term use of the thrombopoietin-mimetic romiplostim in children with severe chronic immune thrombocytopenia (ITP). Pediatr Blood Cancer. Epub 2014 Oct 24.

30. Bussel JB, Buchanan GR, Nugent DJ, et al. A randomized, double-blind study of romiplostim to determine its safety and efficacy in children with immune thrombocytopenia. Blood. 2011;118(1):28-36.

31. Elalfy MS, Abdelmaksoud AA, Eltonbary KY. Romiplostim in children with chronic refractory ITP: randomized placebo controlled study. Ann Hematol. 2011;90(11):1341-1344.
32. Pasquet M, Aladjidi N, Guiton C, et al. Romiplostim in children with chronic immune thrombocytopenia (ITP): the French experience. $\mathrm{Br} J$ Haematol. 2014;164(2):266-271.

33. Choe MJ, Packer CD. Severe romiplostim-induced rebound thrombocytopenia after splenectomy for refractory ITP. Ann Pharmacother. 2015;49(1):140-144.

34. Carpenedo M, Cantoni S, Coccini V, Pogliani EM, Cairoli R. Response loss and development of neutralizing antibodies during long-term treatment with romiplostim in patients with immune thrombocytopenia: a case series. Eur J Haematol. Epub 2015 Dec 31.

35. Bussel JB, Wang X, Lopez A, Eisen M. Case study of remission in adults with immune thrombocytopenia following cessation of treatment with the thrombopoietin mimetic romiplostim. Hematology. Epub 2015 Aug 7.

36. Truven Health Analytics. Micromedex solutions. [homepage on the Internet]. Available from URL: http://micromedex.com/. Accessed November 1, 2016.
Journal of Blood Medicine

\section{Publish your work in this journal}

The Journal of Blood Medicine is an international, peer-reviewed, open access, online journal publishing laboratory, experimental and clinical aspects of all topics pertaining to blood based medicine including but not limited to: Transfusion Medicine; Blood collection, Donor issues, Transmittable diseases, and Blood banking logistics; Immunohematology; Artificial and alternative

\section{Dovepress}

blood based therapeutics; Hematology; Biotechnology/nanotechnology of blood related medicine; Legal aspects of blood medicine; Historical perspectives. The manuscript management system is completely online and includes a very quick and fair peer-review system. Visit http://www.dovepress.com/ testimonials.php to read real quotes from published authors. 